Abstract FRI0095 - Table 1

\begin{tabular}{|c|c|c|c|}
\hline & $\begin{array}{l}\text { anti-TNFa } \\
n=17\end{array}$ & $\begin{array}{l}\text { RTX } \\
n=7\end{array}$ & $\mathbf{P}$ \\
\hline \multicolumn{4}{|l|}{ General features } \\
\hline Sex $(\dot{\varepsilon} / \hat{y})$ & $4 / 2$ & $13 / 5$ & 0.79 \\
\hline Mean age (vears) & $59.1 \pm 18.3$ & $54.28 \pm 10.7$ & 0.49 \\
\hline $\begin{array}{l}\text { Ocular bilateral } \\
\text { involvement }=\end{array}$ & 23.53 & 57.14 & 0.13 \\
\hline $\begin{array}{l}\text { Duration of underlying } \\
\text { diseases (days) }\end{array}$ & $183.06 \pm 18.3$ & $138.85 \pm 77.68$ & 0.59 \\
\hline \multicolumn{4}{|l|}{ Basal } \\
\hline $\mathrm{BCVA}^{\mathrm{*}}$ & $0.58 \pm 0.38$ & $0.56 \pm 0.34$ & 0.68 \\
\hline Peripheral thinnina = & 18 & 9 & 0,77 \\
\hline Central keratolysis $=^{*}$ & $\overline{4}$ & 1 & 0.59 \\
\hline Ocular perforation $=$ & 2 & 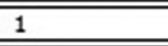 & 0.89 \\
\hline Scleritis $=$ & 3 & 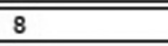 & 0.001 \\
\hline Episcleritis = & 3 & 4 & 0.15 \\
\hline Uveitis $=$ & $\overline{3}$ & $\overline{2}$ & 0.77 \\
\hline \multicolumn{4}{|l|}{ 1" month } \\
\hline $\mathrm{BCVA}^{8}$ & $0.67 \pm 0.31$ & $0.56 \pm 0.27$ & 0.67 \\
\hline Peripheral thinnina $=$ & 5 & 6 & 0.032 \\
\hline Central keratolysis $=^{*}$ & - & - & 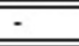 \\
\hline Ocular perforation $=$ & - & - & $\begin{array}{ll}- \\
\end{array}$ \\
\hline Scleritis $=$ & 1 & 1 & 0.54 \\
\hline Episcleritis = & 1 & 0 & 0.45 \\
\hline Uveitis $=$ & 1 & $\overline{2}$ & 0.23 \\
\hline \multicolumn{4}{|l|}{ 6" month } \\
\hline $\mathrm{BCVA}^{\mathrm{8}}$ & $0.7 \pm 0.25$ & $0.73 \pm 0.29$ & 0.67 \\
\hline Peripheral thinning = & 9 & 3 & 0.14 \\
\hline Centralkeratolysis $=^{*}$ & 0 & 3 & 0.028 \\
\hline Ocular perforation $=$ & - & - & - \\
\hline Scleritis $=$ & - & $=$ & $=$ \\
\hline Episcleritis = & - & - & - \\
\hline Uveitis $=$ & 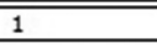 & 0 & 0.38 \\
\hline \multicolumn{4}{|l|}{ 1st year } \\
\hline $\mathrm{BCVA}^{\mathrm{P}}$ & $0.75 \pm 0.22$ & $0.70 \pm 0.24$ & 0.77 \\
\hline Peripheral thinning = & 7 & 3 & 0.25 \\
\hline Centralkeratolysis $=^{8}$ & 1 & 1 & 0.89 \\
\hline Ocular perforation $=$ & 0 & 1 & 0.30 \\
\hline Scleritis $=$ & - & - & - \\
\hline Episcleritis = & - & - & - \\
\hline Uveitis = & 1 & 0 & 0.35 \\
\hline
\end{tabular}

Comparisons. were made between baseline and 1 st month, 6th month and 1 st year (STATISTICA, StatSoft Inc. Tulsa, Oklahoma, USA). Quantitative variables were expressed as mean $\pm S D$ or median [IQR], accordingly to its distribution. They were compared with the Student t or the Mann-Whitney U test respectively. Dichotomous variables were expressed as percentages and compared by the chisquare test.

Results: We studied 24 patients/32 affected eyes. The underlying diseases in the anti-TNF $\alpha$ group were Rheumatoid Arthritis $(R A)(n=14)$, Psoriatic Arthritis $(n=2)$ and Behçet Disease $(n=1)$; and in the RTX group: RA ( $n=5)$, granulomatous polyangiitis $(n=1)$ and microscopic polyangiitis $(n=1)$.

At baseline there were no significant differences between both groups in general features or in ocular involvement (table 1). Before biologic therapy they had received the following systemic drugs (anti-TNF $\alpha$ vs RTX) i.v. methylprednisolone ( 2 vs 4 ), doxycycline ( 7 vs 1 ), ascorbic acid ( 2 vs 0 ), MTX (11 vs 4), AZA (1 vs 2 ) and others (7 vs 3). In addition, 10 patients, in both groups, had required surgery: amniotic membrane $(n=5)$, penetrating keratoplasty $(n=2)$, conjunctival resection $(n=2)$, tissue adhesives $(n=2)$, conjunctival flap $(n=1)$ and lamellar keratoplasty $(n=1)$.

Once the treatment was initiated the ocular outcome was similar (table 1).

After a mean follow-up of $22.53 \pm 22.60$ (anti-TNF $\alpha$ ) and $22.28 \pm 8.28$ months with RTX the following severe side effects were observed: supraventricular tachycardia $(n=1)$ with $R T X$ and pulmonary tuberculosis $(n=1)$ with IFX.
Conclusions: In this study, anti-TNF $\alpha$ therapy and RTX were equally effective for the treatment of peripheral ulcerative keratitis associated to rheumatic diseases refractory to conventional treatment.

Disclosure of Interest: None declared

DOI: 10.1136/annrheumdis-2018-eular.2622

\section{FRI0096 IS SIDE EFFECTS AND TREATMENT RESPONSE TO METHOTREXATE ASSOCIATED TO COMORBIDITY IN EARLY RHEUMATOID ARTHRITIS}

K.L. Pedersen ${ }^{1}$, J. Hallas ${ }^{2}$, I.M.J. Hansen ${ }^{3}$, P. Ahlquist ${ }^{4}$, T. Ellingsen ${ }^{5} .{ }^{1}$ Hospital $^{\prime}$ Pharmacy of Funen, Odense University Hospital; ${ }^{2}$ Clinical Pharmacology and Pharmacy, Department of Public Health; ${ }^{3}$ Dept of Rheumatology, Odense University Hospital; ${ }^{4}$ Reumaclinic Funen, Reuamaclinic Funen; ${ }^{5}$ Rheumatology, Odense University Hospital, Odense, Denmark

Background: In Denmark approximately $0.7 \%$ (35.000) of the population is diagnosed with rheumatoid arthritis $(R A)$. RA is a risk factor in development of comorbidity, and comorbidities are not well managed in RA patients. In addition of being first line treatment of early RA, methotrexate (MTX) gives a 70\% reduction in cardiovascular disease caused mortalities, and if treatment exceeds a year, the general mortality risks are lowered by $60 \%$. Discontinuation of MTX is therefore a bad outcome for RA. It remains unclear whether side effects and treatment response to MTX is associated to comorbidity in early RA.

Objectives: To evaluate the association between comorbidity and persistence to MTX treatment and side effects for RA patients.

Methods: Patient files from three centres were evaluated retrospectively. Inclusion criteria were: diagnosis obtained according to $A C R / /$ ULAR 2010 criteria for RA in the period 01/01/2010 to present, and MTX as first line of treatment. Medical records were reviewed for side effects, dose changes of MTX, formulation changes and persistence. Comorbidities and comedication was evaluated by usage of the Danish National Patient Registry (DNPR), and the Odense Pharmacoepidemiological Database (OPED). Comorbidities were scored according to the Charlson Comorbidity Index (CCl), and analysed by the cox proportional hazards model for discontinuation of MTX treatment and dose reduction.

Results: 501 patients were screened, 177 were eligible and analysed at baseline for disease characteristics, medication besides MTX and comorbidities in a 5 yea window before RA diagnosis baseline. The highest risk of MTX discontinuation was a CCl of 3-4, they had crude $4.18(95 \% \mathrm{Cl} 1.67-10.45)$ increased risk compared to the reference group (RA with no comorbidities). Risk of dosage reduction was highest at CCI 1-2: $1.38(95 \% \mathrm{Cl} 0.72-2.62)$. A CCl of 5 or higher gave a $-4.83 \mathrm{mg}(95 \% \mathrm{Cl}-10.24--0.59)$ adjusted difference in maximum weekly tolerable MTX dosage. Side effects occurred for $23.7 \%$. Most likely dosage causing side effect was $20 \mathrm{mg}$ (IQR 15-20 mg). Nausea occurred in 29\% and hepatic events $21 \%$.

Conclusions: Patients with $\mathrm{CCl}$ in the range of $3-4$ had an increased risk for discontinuing MTX treatment.

Disclosure of Interest: None declared

DOI: 10.1136/annrheumdis-2018-eular.2608

\section{FRI0097 EXPRESSION OF UNCOUPLING PROTEIN-1 IN SUBCUTANEOUS FAT REDUCES THE TOTAL CHOLESTEROL LEVEL AND CARDIOVASCULAR RISK IN FEMALE RA PATEINTS}

L.I. Lyngfelt, M.C. Erlandsson, M. Nadali, K.M. Andersson, S.T. Silfverswärd, R. Pullerits, M.I. Bokarewa. Department of Rheumatology and Inflammation Research, University of Gothenburg, Gothenburg, Sweden

Objectives: To improve understanding of fat-related molecular mechanisms behind the increased cardiovascular (CV) morbidity in patients with rheumatoid arthritis (RA).

Methods: Transcription of uncoupling protein 1 (UCP1) was measured in the subcutaneous fat tissue and serum levels of lipoproteins, adipokines, and inflammation markers in 185 middle-aged female patients (mean age 51 years) with RA and compared between the groups stratified by the total cholesterol (TC) levels and the body mass index (BMI). The risk of dying of CV disease within 5 years was calculated electronically using the strategy proposed by Pocock et al. ${ }^{1}$

Results: CVR was highest (risk score 27.76, 5 year CVR $0.67 \%$ ) in the patients combining high TC $(>5.1 \mathrm{mmol} / \mathrm{L})$ and high BMI $(>25 \mathrm{~kg} / \mathrm{m} 2)$, while those with low levels of TC and BMI had lowest CVR (risk score 10.82, CVR 0.11\%). CVR was significantly decreased if either $\mathrm{TC}\left(\mathrm{TC}^{\mathrm{lo}} \mathrm{BMI} \mathrm{l}^{\mathrm{hi}}\right)$ or $\mathrm{BMI}\left(\mathrm{TC}^{\text {hi }} \mathrm{BMI} \mathrm{I}^{\mathrm{lo}}\right)$ was low $\left(p=0.017\right.$ and $p=0.014$, respectively). With the exception of $\mathrm{TC}^{\mathrm{lo}} \mathrm{BM} \mathrm{l}^{\mathrm{lo}}$ group, these groups had no difference with respect to age, disease duration, inflammation defined by serum IL 6 and IL 1 , and disease activity measured by DAS28. $\mathrm{TC}^{\mathrm{lo}} \mathrm{BMl} \mathrm{I}^{\mathrm{hi}}$ patients had an overall increase in fat expression of UCP1 $(\mathrm{p}=0.047)$ that has the cholesterol lowering capacity and may explain low TC levels in this 
group. In contrast, $\mathrm{TC}^{\text {hi }} \mathrm{BMI}^{\mathrm{lo}}$ patients had high prevalence of cases with unmeasurable UCP1 expression and higher levels of serum adiponectin $(p=0.053)$ and HDL $(p<10-5)$.

Measurable expression of UCP1 was found in $79 \%$. In total cohort, the patients with measurable UCP1 had higher inflammation and RA activity presented by IL-6 $(p=0.0001), I L 1 b(p=0.037)$ and DAS28 $(p=0.0086)$, compared to those with no UCP1 expression. $\mathrm{TC}^{\mathrm{lo}} \mathrm{BMI} \mathrm{I}^{\mathrm{hi}}$ patients had an overall increase in fat expression of UCP1 $(p=0.047)$ and lowest prevalence of cases with no UCP1 expression (6.2\%)

Conclusions: The study shows that UCP-1 expression in subcutaneous fat may be a CV protective mechanism in RA patients. The inflammation seems to be the driving force of UCP1 expression in RA.

\section{REFERENCE:}

[1] Pocock SJ, McCormack V, Gueyffier F, Boutitie F, Fagard RH, Boissel JP. A score for predicting risk of death from cardiovascular disease in adults with raised blood pressure, based on individual patient data from randomised controlled trials. BMJ 2001;323:75-81.

Disclosure of Interest: None declared

DOI: 10.1136/annrheumdis-2018-eular.4814

\section{FRI0098 HEPATIC SAFETY IN PATIENTS WITH RHEUMATOID ARTHRITIS WHO RECEIVED ISONIAZID FOR LATENT TUBERCULOSIS: POST-HOC ANALYSIS FROM PHASE 3 BARICITINIB STUDIES}

T.-Y. Hsieh ${ }^{1}$, W.-N. Huang ${ }^{1}$, H.-P. Tony ${ }^{2}$, A. Balsa ${ }^{3}$, K. Winthrop ${ }^{4}$, M. Harigai ${ }^{5}$, C. Dickson ${ }^{6}$, W.-S. Wu ${ }^{7}$, I. de la Torre ${ }^{8}$, R. Liao $^{6}$, L. Chen ${ }^{6}$, S. Kumar ${ }^{6}$, B. Combe ${ }^{9}$ ${ }^{1}$ Department of Internal Medicine, Taichung Veterans General Hospital, Taichung, Taiwan, Province of China; ${ }^{2}$ Rheumatologie, Klinische Immunologie, Klinikum der Universität Würzburg, Würzburg, Germany; ${ }^{3}$ Department of Rheumatology, Hospital Universitario La Paz, Madrid, Spain; ${ }^{4}$ Center for Infectious Disease Studies, OHSU-PSU School of Public Health, Portland, USA; ${ }^{5}$ Institute of Rheumatology, Tokyo Women's Medical University, Tokyo, Japan; ${ }^{6}$ Eli Lilly and Company, Indianapolis, USA; ${ }^{7}$ Eli Lilly and Company, Taipei, Taiwan, Province of China; ${ }^{8}$ Eli Lilly and Company, Madrid, Spain; ${ }^{9}$ Départment of Rheumatology, Montpellier University Hospital, University of Montpellier, Montpellier, France

Background: Baricitinib (BARI) is an oral selective Janus kinase (JAK 1/2) inhibitor approved in the EU, Japan, and other countries for treatment (tx) of moderately to severely active rheumatoid arthritis (RA) in adults. RA therapies may increase risk of tuberculosis (TB). ${ }^{2}$ The use of isoniazid (INH) plays a vital role to control TB. However, INH may result in hepatic adverse events (AEs) ${ }^{3}$. Limited data exist on hepatic safety in TB patients (pts) with RA treated with JAK inhibitors and INH.

Objectives: To evaluate the hepatic safety in pts with $\mathrm{RA}$, who were receiving INH for latent TB (LTBI) in BARI phase 3 trials.

Methods: This is a descriptive post-hoc analysis of three phase 3 studies: RABEAM, RA-BUILD, and RA-BEACON. All pts were screened for LTBI prior to randomisation. Pts with untreated LTBI and without documentation of prior completed tx, received INH at least for 4 weeks (wk) prior to randomisation and during the clinical trial period. Changes in ALT levels $(\geq 1 X, \geq 3 X, \geq 5 X$, and $\geq 10 X$ of ULN) from baseline up to 24 wk were analysed by tx groups (BARI $4 \mathrm{mg}$, BARI 2 mg, adalimumab [ADA], and placebo [PBO]).

Results: In total, 2516 pts were included in this analysis. Of these, 891 pts were treated with BARI 4 mg, 403 with BARI 2 mg, 330 with ADA, and 892 with PBO. Background csDMARDs, mainly methotrexate (MTX) were continued. Overall, 246 pts reported LTBI at screening across all tx groups. Of these, 169 with confirmed lab data received INH as LTBI tx. At wk 24, ALT $\geq 1 \mathrm{X}$ was reported in 24 $(41.4 \%)$ pts receiving BARI 4-mg+INH. None of the pts in BARI 4-mg+INH reported ALT level of $\geq 3 \mathrm{X}, \geq 5 \mathrm{X}$, and $\geq 10 \mathrm{X}$ ULN. For BARI $2-\mathrm{mg}+\mathrm{INH}, \mathrm{ALT} \geq 1 \mathrm{X}$ reported in $9(33.3 \%)$ pts, $A L T \geq 3 X$ in 2 (7.4\%), ALT $\geq 5 X$ in 1 (3.7\%), and $A L T \geq 10 X$ in $1(3.7 \%)$ of the pts. Among pts treated with $A D A+I N H, A L T \geq 1 X$ was reported in 12 (44.4\%), ALT $\geq 3 X$ in $2(7.4 \%), A L T \geq 5 X$ in 1 (3.7\%), and $A L T \geq 10 X$ in none of pts. Among pts treated with $\mathrm{PBO}+\mathrm{INH}, \mathrm{ALT} \geq 1 \mathrm{X}$ was reported in 21 (36.8\%), ALT $\geq 3 X$ and $A L T \geq 5 X$ levels were reported in 2 (3.5\%, for both) of the pts. None of the pts reported $A L T \geq 10 X$. One pt receiving INH in RA-BEAM PBO arm had temporary interruption of tx due to abnormal hepatic lab results. No study tx interruption or discontinuation was reported in INH users in BARI or ADA groups due to abnormal hepatic lab results.
Abstract FRI0098 - Table 1. Changes in ALT level from baseline to week 24 in patients receiving $B A R I, A D A$, and $P B O$

\begin{tabular}{|c|c|c|c|c|c|c|c|c|}
\hline & \multicolumn{2}{|c|}{$\begin{array}{c}\text { BARI 4-mg } \\
\text { (RA-BEAM, RA-BUILD, } \\
\text { RA-BEACON) } \\
\mathrm{N}=891\end{array}$} & \multicolumn{2}{|c|}{$\begin{array}{c}\text { BARI 2-mg } \\
\text { (RA-BUILD, RA- } \\
\text { BEACON) } \\
\mathrm{N}=403\end{array}$} & \multicolumn{2}{|c|}{$\begin{array}{c}\text { ADA } \\
\text { (RA-BEAM) } \\
N=330\end{array}$} & \multicolumn{2}{|c|}{$\begin{array}{c}\text { PBO } \\
\text { (RA-BEAM, RA-BUILD, } \\
\text { RA-BEACON) } \\
N=892\end{array}$} \\
\hline & $\begin{array}{c}\text { INH } \\
(n=58)\end{array}$ & $\begin{array}{l}\text { No INH } \\
(n=833)\end{array}$ & $\begin{array}{c}\text { INH } \\
(n=27)\end{array}$ & $\begin{array}{l}\text { No INH } \\
(n=376)\end{array}$ & $\begin{array}{c}\mathrm{NH} \\
(\mathrm{n}=27)\end{array}$ & $\begin{array}{l}\text { No INH } \\
(n=303)\end{array}$ & $\begin{array}{c}\text { INH } \\
(\mathrm{n}=57)\end{array}$ & $\begin{array}{l}\text { No INH } \\
(n=835)\end{array}$ \\
\hline $\begin{array}{l}\text { ALT } \\
\geq 1 X \\
\text { ULN }\end{array}$ & $\begin{array}{c}24 \\
(41.4 \%)\end{array}$ & $\begin{array}{c}260 \\
(31.2 \%)\end{array}$ & $9(33.3 \%)$ & $\begin{array}{c}82 \\
(21.8 \%)\end{array}$ & $\begin{array}{c}12 \\
(44.4 \%)\end{array}$ & $\begin{array}{c}91 \\
(30.0 \%)\end{array}$ & $21(36.8 \%)$ & $\begin{array}{c}183 \\
(21.9 \%)\end{array}$ \\
\hline $\begin{array}{l}\text { ALT } \\
\geq 3 X \\
\text { ULN } \\
\end{array}$ & 0 & $13(1.6 \%)$ & $2(7.4 \%)$ & $6(1.6 \%)$ & $\begin{array}{c}2 \\
(7.4 \%)\end{array}$ & $9(3.0 \%)$ & $2(3.5 \%)$ & $13(1.6 \%)$ \\
\hline $\begin{array}{l}\text { ALT } \\
\geq 5 X \\
\text { ULN }\end{array}$ & 0 & $5(0.6 \%)$ & $1(3.7 \%)$ & $1(0.3 \%)$ & $\begin{array}{c}1 \\
(3.7 \%)\end{array}$ & $3(1.0 \%)$ & $2(3.5 \%)$ & $3(0.4 \%)$ \\
\hline $\begin{array}{c}\text { ALT } \\
\geq 10 X \\
\text { ULN }\end{array}$ & 0 & $2(0.2 \%)$ & $1(3.7 \%)$ & 0 & 0 & $1(0.3 \%)$ & 0 & 0 \\
\hline
\end{tabular}

All pts were on concomitant use of csDMARDs, mainly MTX.

Conclusions: The percentage of pts with $\geq 1 \mathrm{X}$ ULN ALT was numerically higher in INH group vs no INH and was consistent across PBO, BARI and ADA tx groups. The data do not suggest an increased hepatic safety risk in pts treated with BARI who were receiving concomitant INH.

\section{REFERENCES:}

[1] Dougados M, et al. Ann Rheum Dis. Jan 2017;76(1):88-95.

[2] Lim CH, et al. PLoS One. 2017;12(6):e0178035.

[3] Vanhoof J, et al. Ann Rheum Dis. Dec 2003;62(12):1241-1242.

Disclosure of Interest: T.-Y. Hsieh: None declared, W.-N. Huang: None declared, H.-P. Tony Consultant for: Abbvie, AstraZeneca, Chugai, Janssen Cilag, Eli Lilly and Company, Novartis, Roche, Sandoz Hexal, A. Balsa Grant/ research support from: Pfizer, AbbVie, UCB, Roche, Novartis, Consultant for: Pfizer, Novartis, AbbVie, MSD, UCB, Roche, BMS, Novartis, Celltrion, Nordic, K. Winthrop Grant/research support from: Pfizer, BMS, Consultant for: Pfizer, UCB, Abbvie, Eli Lilly and Company, Amgen, BMS, M. Harigai Grant/research support from: BristolMyers Squibb K.K., Eisai Co., Ltd., Ono Pharmaceuticals, and Takeda Pharmaceutical Co., Ltd., Consultant for: Eli Lilly and Company, C. Dickson Employee of: Eli Lilly and Company, W.-S. Wu Shareholder of: Eli Lilly and Company, Employee of: Eli Lilly and Company, I. de la Torre Employee of: Eli Lilly and Company, R. Liao Employee of: Eli Lilly and Company, L. Chen Shareholder of: Eli Lilly and Company, Employee of: Eli Lilly and Company, S. Kumar Employee of: Eli Lilly and Company, B. Combe Grant/research support from: Pfizer, UCB, Consultant for: Abbvie, BMS, Janssen, Lilly, MSD, Novartis, Pfizer, Roche-Chugai, UCB, Speakers bureau: BMS, Janssen, Lilly, MSD, Pfizer, Roche-Chugai, UCB

DOI: 10.1136/annrheumdis-2018-eular.1922

\begin{tabular}{|l|l}
\hline FRI0099 & LIVER ENZYME ABNORMALITIES AFTER TOFACITINIB \\
TREATMENT IN PATIENTS WITH HEPATIC STEATOSIS \\
FROM THE RHEUMATOID ARTHRITIS, PSORIATIC \\
ARTHRITIS AND PSORIASIS CLINICAL PROGRAMMES
\end{tabular}

E.R. Soriano ${ }^{1}$, H. Madariaga ${ }^{2}$, O. Castañeda ${ }^{3}$, G. Citera ${ }^{4}$, E.E. Schneeberger ${ }^{4}$, M. H. Cardiel ${ }^{5}$, T. Hendrikx ${ }^{6}$, D. Graham ${ }^{7}$, H. Shi ${ }^{6}$, D. Ponce de Leon ${ }^{8} .{ }^{1}$ Hospital Italiano de Buenos Aires, Buenos Aires, Argentina; ${ }^{2}$ Clínica del Sur, Arequipa; ${ }^{3}$ Clínica Anglo Americana, Lima, Peru; ${ }^{4}$ Instituto de Rehabilitación Psicofísica, Buenos Aires, Argentina; ${ }^{5}$ Centro de Investigación Clínica de Morelia, Morelia, Mexico; ${ }^{6}$ Pfizer Inc, Collegeville, PA; ${ }^{7}$ Pfizer Inc, Groton, CT, USA; ${ }^{8}$ Pfizer Inc, Lima, Peru

Background: Non-alcoholic fatty liver disease, characterised by hepatic steatosis (HS), is a major cause of chronic liver disease in many countries. Limited data are available on liver enzyme elevation in patients (pts) with $\mathrm{HS}$ who are receiving medications for inflammatory conditions, such as rheumatoid arthritis (RA), psoriatic arthritis (PsA) and psoriasis (PsO). Tofacitinib is an oral Janus kinase inhibitor for the treatment of RA and PsA, and has also been studied in PsO.

Objectives: To describe baseline characteristics and liver enzyme abnormalities in pts from the tofacitinib RA, PsA and PsO clinical programmes with/without HS at baseline.

Methods: Pts randomised to the tofacitinib (5 or $10 \mathrm{mg}$ twice daily; doses pooled) and placebo arms of 25 studies in the RA, PsA and PsO programmes were 